\title{
EFFECT OF RUELLIA PRAETERMISSA EXTRACTS ON ERYTHROPOIESIS IN PREGNANT WOMEN
}

\author{
SALAH A. MARTIN ${ }^{1}$, NJUNDA L. ANNA ${ }^{2}$ \\ ${ }^{1}$ Department of Animal Physiology, Faculty of Science, University of Buea, P.O. Box 63 Buea, Cameroon. \\ ${ }^{2}$ Department of Medical Laboratory Sciences, Faculty of Health Science, University of Buea, Cameroon.
}

\begin{abstract}
The effect of the extracts of Ruellia Praetermissa on hemoglobin $(\mathrm{Hb})$, Hematocrit $(\mathrm{Ht})$, mean corpuscular hemoglobin (MCH), mean corpuscular volume (MCV). mean corpuscular hemoglobin concentration $(M C H C)$, red blood cell count $(R B C)$, was investigated in 50 Pregnant women attending prenatal clinic in Belo maternity. The women were assigned to 5 groups of 10 women per group. The first group was the control and the other 4 were the experimental groups. The control was administered daily, $0.5 \mathrm{ml}$ of saline solution while the experimental groups were administered daily oral doses of the plant extract in concentrations of $200 \mathrm{mg} / \mathrm{kg}, 400 \mathrm{mg} / \mathrm{kg}$, $800 \mathrm{mg} / \mathrm{kg}$ and $1,600 \mathrm{mg} / \mathrm{kg}$ respectively for 16 days. Blood samples were collected on the $17^{\text {th }}$ day and analyzed. The extracts contain flavonoids aglycons (Iuteolin and apigenin) and their respective, glycosides and a high concentration of triterpens (campesterol, stigmasterol, -sitosterol, lupeol) and iridoid glycosides. It is also rich in vitamins and minerals. The extracts increased the values in a dose dependent manner $H b(P<0.05), R B C(P<0.05)$, hematocrit $(P<0.05)$. It however showed no remarkable effect on the values of $M C H$ and $M C H C(P>0.05)$ but with a dose depending decreasing effect on MCV $(P<0.05)$. The active principles of this plant drug stimulate erythropoiesis which leads to increase in circulating RBCs with slightly microcytic sizes (MCV), normochromic weight, (MCH) normochromic hemoglobin contents (MCHC). The result of this study thus supports the traditional use of Ruellia Praetermissa in pregnancies threatened with miscarriage and as a remedy for anemia.
\end{abstract}

Keywords: Ruellia Praetermissa; Pregnant Women, Blood

(Bangladesh J Physiol Pharmacol 2012;28(1\&2):15-18)

\section{INTRODUCTION}

Gestational problems are a potential source of mortality for both gestation mothers and their developing fetuses in the underdeveloped world in general and Africa in particular. There is great need for effective safe prenatal drugs from natural sources which are available and affordable with respect to modern medicines.

Ruellia praetermissa is a wild herb and indigenous to central and south eastern Asia and also widespread in tropical and subtropical Africa. In the North West Region of Cameroon it enjoys a folk reputation as blood and pregnancy medicine. In other south Eastern African countries; it is widely applied to relief pain. ${ }^{1}$ The Plant drug exerts estrogenic and cholinergic effects. ${ }^{2}$ The extracts regularizes pregnancies threatened with miscarriages in early stages. This is due to its ability to mimic $17 \beta$-estradiol. It stimulates the growth of the uterine endometrium. This is by the proliferation and the development of the cells of the uterine endometrium as it up-regulates estrogen, $\mathrm{LH}$ and progesterone receptors on the uterine muscles at the beginning of gestation and to excite the uterine myometrium at term. ${ }^{2}$ In addition, the extracts of this plant drug has a stimulatory effects on the motility of the gastrointestinal tract $^{3}$ and antihypertensive effect by the Inhibition of Angiotensin-Converting Enzyme activity. ${ }^{4}$ These biological effects are of particular interest since high blood pressure and indigestion frequently characterise gestation period. This herbal drug is rich in flavonoids such as luteolin, quercetin and apigenin. ${ }^{5}$ The favonoids also have an antispasmodic effects on uterine smooth muscle. ${ }^{6}$ The plant extract has 5-Lipoxygenase inhibition and antisplasmodic effects. ${ }^{7}$ The plant drug promotes implantation, and stabilizes the uterine endometrium in female rats. ${ }^{8}$

The present study is aimed at finding out the scientific basis of the use of Ruellia praetermissa as a prenatal herbal drug in the North-Western region of Cameroon. 


\section{MATERIALS AND METHODS}

\section{Plant Material}

The plant material was collected in Belo, North West Province of Cameroon in September 2011. The specimen was verified and authenticated as the one earlier identified by Kofany of the Cameroon National Herbarium Obili Yaounde under the voucher specimen number 43596 deposited in 1996.

\section{Extraction and sample preparation}

Sun dried leaves of the plant were pulverized and $250 \mathrm{~g}$ was extracted using the sohxlet for 12 hours in each case progressively with 2 I of n-hexane, chloroform, ethyl acetate, and methanol. The extracts (160, 140, 250 and $300 \mathrm{mg}$, respectively) were recovered by rotavaporization. The chaffs were boiled in water at $85{ }^{\circ} \mathrm{C}$ for 6 hours and $225 \mathrm{mg}$ of extract was recovered by lyophilization. The procedure was repeated 20 times to obtain the plant drug supplies necessary for the whole investigation.

\section{Plant Drug Analysis}

\section{a. TLC}

The ethyl acetate extract $(5 \mathrm{mg}$ ) was cochromatographed with flavonoid test samples (rutin, chlorogenic acid, hyperoside and isochlorogenic acid), luteolin and luteolin-7-glucoside, quercetin, isoquercetin, delphinidin and caffeic acid using ethyl acetate-formic acid -glacial acetic acid-water (100:11:11:26) as the mobile phase and precoated silica gel $60 \mathrm{~F}_{254}(20 \times 20$ thickness $0.25 \mathrm{~mm}$ Merck, Darmstadt, Germany) as the stationary phase. The plate was first observed at $U_{254} \mathrm{~nm}$ then sprayed with natural products-polyethylene glycol reagent (NP/PEG) and evaluated at $\mathrm{UV}_{366} \mathrm{~nm}$.

\section{b. HPLC}

This was carried out with an HP 1090 A liquid chromatography and an HP 1040 photodiode array with a Hewlett Packard detector as a LiChrospher 100 RP 18 $(5 \mu \mathrm{m})$ column $125 \times 4 \mathrm{~mm}$ (Merck, Darmstadt, Germany), and a precolumn LiChrospher RP-18 4-4 mm

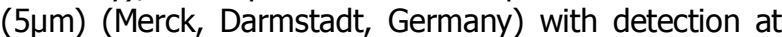
wavelength $210 \mathrm{~nm}, 254 \mathrm{~nm}, 280 \mathrm{~nm}$ and $366 \mathrm{~nm}$. The mobile phase used for the separation was distilled water (Solvent A) and acetonitrile (Solvent B), all acidified with $33 \mu \mathrm{L}$ of phosphoric acid (85\%). It was started at $10 \%$ of solvent $\mathrm{B}$ and a linear gradient of $10-30 \% \mathrm{MeCN}$ during $20 \mathrm{~min}$ for a total run of $30 \mathrm{~min}$, at a flow of 1 $\mathrm{mL} / \mathrm{min}$, and a volume of $12.5 \mu \mathrm{L}$ of $1 \mathrm{mg} / \mathrm{mL}$ of Ethyl Acetate extract of Ruellia praetermissa was injected.

\section{Experimental Subjects}

The study was conducted in Boyo, and Bamenda in the North West Region of Cameroon from December
2011 to April 2012. A total of 50 Pregnant women between 20 and 40 years of age attending routine prenatal clinics in Belo Maternity Center were recruited for the study. They gave their informed consent to participate in the study which was approved by the ethics commission of our institution. All participants were interviewed to assess their physical wellness, nutritional factors, gestational history and hematological records. The women were assigned to 5 groups of 10 each. The first group was the control which received daily doses of $0.5 \mathrm{ml}$ of saline solution. The second, third, fourth and fifth groups received $200 \mathrm{mg} / \mathrm{kg}$, $400 \mathrm{mg} / \mathrm{kg}, 800 \mathrm{mg} / \mathrm{kg}$ and $1,600 \mathrm{mg} / \mathrm{kg}$ respectively in daily oral doses for sixteen days. Blood samples $(0.5 \mathrm{ml})$ were obtained on the $17^{\text {th }}$ day from each of the women. This was done with needles and syringes in $10 \mathrm{ml}$ tubes using venous puncture by drawing specimens from a superficial vein in the antecubital fossa of the arm. Ethylenediamine tetraacetic acid (EDTA) was used to prevent blood from clotting. These samples were analyzed in the Diagnostic Laboratory in Bamenda for the determination of blood parameters under investigation: Hematocrit ( $\mathrm{Ht})$, Hemoglobin Concentration $(\mathrm{Hb})$, and Red blood Cell Counts (RBC),

\section{Blood Analysis}

The Hct was measured by the percentage of the total blood volume that is made up of RBCs. The height of the RBCs column was measured after centrifugation and compared to the column of the total whole blood. The ratio of the height of the RBC column compared with the original total blood column was multiplied by $100 \%$ and that was recorded as the Hct value. The haemoglobin value and the red blood cell count were done by an automated cell counter. The values of RBC, hematocrit, and haemoglobin test were used tocalculate the RBC indices (MCV, $\mathrm{MCH}$ and $\mathrm{MCHC}$ ).

\section{Statistical Analysis}

Data was analysed using Sigma Plot 11 for Windows and the significance was set at the $5 \%$ level. The results were expressed as mean \pm SEM, differences between means analysed using Student-t-test. $P$ values of 0.05 or less and 0.001 were taken as being statistically significant.

\section{RESULTS AND DISCUSSION}

The results of the chemical analysis of the four extracts revealed that the pant drug contains flavonoids aglycons (luteolin and apigenin) and their respective, glycosides. The extract also contains a high concentration of triterpens (campesterol, stigmasterol, _-sitosterol, lupeol) and iridoid glycosides.

The effect of various doses of the extract of Ruellia Praetermissa on the mean hematological parameters are shown in Tables $1 \& 2$ below. 
Table I

Effect of the Extract of Ruellia Praetermissa on the Hemtaocrit (Htc) haemoglobin concentration and red blood cell count in the pregnant women blood

\begin{tabular}{cccc}
\hline $\begin{array}{c}\text { Treatment with } \\
\text { Ruellia Extract }\end{array}$ & (Hct) (\%) \pm S.E. & Hb(g/dL) \pm S.E. & RBC (million/mm $\left.\mathbf{m}^{\mathbf{3}}\right) \pm$ S.E. \\
$0.5 \mathrm{ml}$ Saline & $43.35 \pm 1.82$ & $13.26 \pm 1.5$ & $4.10 \pm 0.23$ \\
$200 \mathrm{mg} / \mathrm{kg}$ & $43.90 \pm 2.06$ & $13.34 \pm 1.7$ & $4.34 \pm 0.18$ \\
$400 \mathrm{mg} / \mathrm{kg}$ & $46.62 \pm 1.60$ & $14.75 \pm 0.14$ & $4.80 \pm 1.03$ \\
$800 \mathrm{mg} / \mathrm{kg}$ & $47.75 \pm 1.50$ & $15.22 \pm 0.19$ & $5.33 \pm 0.03$ \\
$1600 \mathrm{mg} / \mathrm{kg}$ & $48.25 \pm 1.49$ & $16.10 \pm 0.07$ & $5.53 \pm 1.1$ \\
\hline
\end{tabular}

Hematocrit (Ht): Increasing the dosage concentration of the plant drug had an effect of increasing the Hematocrit $(\mathrm{Ht})$ in all the treatment groups. Hematocrit $(\mathrm{Ht})$ value at $200 \mathrm{mg} / \mathrm{kg} 43.90 \pm 2.06 \%$ was however not significantly different from that of the control group $43.35 \pm 1.82 \%$. At high doses of the extract, $800 \mathrm{mg} / \mathrm{kg}$ and $1,600 \mathrm{mg} / \mathrm{kg}$, there was a significant increase from $47.75 \pm 1.5 \%$ to $48.25 \pm 1.49 \%$ respectively $(P<0.05)$.

Hemoglobin Concentration (Hb)): Increase in hemoglobin concentration occurred with increased concentration of applied extract. The hemoglobin value of $13.26 \pm 1.5 \mathrm{~g} / \mathrm{dL}$ of the control group increased to
$15.22 \pm 0.19 \mathrm{~g} / \mathrm{dL}$ at $800 \mathrm{mg} / \mathrm{kg}$ and $16.10 \pm 0.07 \mathrm{~g} / \mathrm{dL}$ at $1,600 \mathrm{mg} / \mathrm{kg}$ respectively. All these values are significantly different from the control group $(P<$ 0.05). Significant change in hemoglobin concentration also occurred between the two high doses i.e. 800 and $1,600 \mathrm{mg} / \mathrm{kg}$.

Red Blood Cell Count: Women that received 200 and $400 \mathrm{mg} / \mathrm{kg}$ body weight of the extract had significantly lower red cell value $\mathrm{P}<0.05$ than those who received 800 and $1,600 \mathrm{mg} / \mathrm{kg}$ body weight of the extract. There was no significant difference between the red cell count of those that received $200 \mathrm{mg} / \mathrm{kg}$ dose of extract and the normal saline in the control group.

Table II

Effect of the Extract of Ruellia Praetermissa on the Blood indices(mean corpuscular volume [MCV], Mean corpuscular haemoglobin [MCV], and Mean corpuscular haemoglobin concentration [MCHC]).

\begin{tabular}{cccc}
\hline $\begin{array}{c}\text { Treatment with Ruellia } \\
\text { Extract }\end{array}$ & MCV \pm S.E. $\left(\mathbf{m m}^{\mathbf{3}}\right)$ & MCH \pm S.E. (Pg) & MCHC \pm S.E. (g/dL) \\
0.5ml Saline & $105.68 \pm 2.92$ & $32.34 \pm 1.4$ & $30.58 \pm 1.1$ \\
$200 \mathrm{mg} / \mathrm{kg}$ & $101.15 \pm 0.50$ & $30.73 \pm 1.73$ & $30.38 . \pm .1 .7$ \\
$400 \mathrm{mg} / \mathrm{kg}$ & $96.26 \pm 1.06$ & $36.56 \pm 0.25$ & $31.63 \pm 1.5$ \\
$800 \mathrm{mg} / \mathrm{kg}$ & $89.58 \pm 1.72$ & $28.55 \pm 0.53$ & $32.87 \pm 2.43$ \\
$1600 \mathrm{mg} / \mathrm{kg}$ & $87.25 \pm 1.35$ & $29.11 \pm 1.39$ & $33.36 \pm 1.14$ \\
\hline
\end{tabular}

\section{MCV, MCH AND MCHC}

Women in the control group who received only normal saline had significantly higher MCV values $(P<0.05)$ than those recorded for all the groups of women who received the extract in various doses. The MCV values decreased in the dose dependent manner. The $\mathrm{MCH}$ and MCHC showed no significant effect $(P>0.05)$ as the plant drugs were administered in different concentrations.

The result of this study showed that the aqueous extract of the leaf sheath of Ruellia Praetermissa increase the overall hemoglobin concentration, red cell count and packed cell volume in Pregnant women in a dose dependent manner. Extract of sorghum has been demonstrated to present similar effects on rats. ${ }^{9}$ However, during pregnancy, there is a decrease in hemtocrit, red blood cell count and Hemoglobin values due to increase ECF volume that increase plasma volume resulting in hemodilution. ${ }^{10}$ This presents a potential source of anemia for the gestation mother which can result in miscarriage. Gestational state also causes physiological polycythemia due to the increase emotional conditions and demand for proton buffering. Hypoxia due to the high demand of respiratory gases for both the gestation mother and the developing fetus also stimulates erythropoietin secretion. ${ }^{11}$ Erythropoietin or erythrocyte stimulating factor is the main hormone responsible for erythropoiesis in bone marrow, liver and spleen. The plant extract extract inhibits Angiotensin converting enzymes (ACE) activity and consequently stimulates the secretion of erythropoietin by peritubular capillaries of the nephron. ${ }^{12}$ Ruellia is a vegetable rich in Vitamin $\mathrm{B}_{12}$ (cyanocobalamin) and minerals such as Iron and copper. ${ }^{13}$ Cyanocobalamin is the major maturation factor necessary for erythropoisis, iron is necessary for 
the formation of the heme part of the haemoglobin and copper is important for the absorption of iron from the gastrointestinal tract. ${ }^{10}$ The iridoid glycosides isolated from this plant drug exerts an inotropic effect of the myocardial muscles ${ }^{7}$ and therefore will increase the cardiac output during pregnancy to satisfy the demands of the developing fetus. ${ }^{14}$ Increase output will also have an increase in erythropoietic activity that will produce more than usual number of erythrocytes. The active principles of this plant drug stimulate erythropoiesis which leads to increase in circulating RBCs with slightly microcytic sizes (MCV), normochromic weight, (MCH) normochromic hemoglobin contents (MCHC). The increase in numbers of erythrocytes containing the same amount and concentration of haemoglobin will fulfil the physiological needs of the pregnant mother with the growing fetus.

In conclusion, this study suggests that administration of Ruellia praetermissa enhances in a dose dependent manner the process of erythropoiesis in gestation mothers and hence counters the anemic effects of pregnancy. In combination with our previous studies on the effects of Ruellia on ovulation, growth of the uterine endometrium, implantation and the estrogenic effects, these findings provide the pharmacological basis for the traditional use of this plant for prenatal care in the North West Region of Cameroon.

\section{ACKNOWLEDGEMENT}

The authors would like to express their gratitude to the Health Board of the Belo Maternity, the ethical committee for the administrative and ethical clearances and all the gestation mothers who accepted to participate in this study.

\section{REFERENCES}

1. Gelfand M, Mavi S, Drummond RB and Ndemera B. The traditional medical practictioner in Zimbabwe: His principles of practice and Pharmacopoeia. Mambo Press 1985: 411.
2. Salah AM, Gathumbi J, Vierling W, Wagner H. Estrogenic and cholinergic properties of the methanol extract of Ruellia praterissa Sceinf.ex.Lindau (Acanthaceae) in female rats. Phytomedicine 2002; 9: 52-55

3. Salah AM, Dongmo AB, Kamanyi A, Bopelet M, Vierling W, Wagner $H$. In vitro purgative effect of Ruellia Praetermissa Scenf.ex.Lidau (Acanthaceae). J Ethnopharmacol 2000; 72: 269-272,

4. Salah $A M$, Dongmo $A B$, Kamanyi $A$, Bopelet $M$, Wagner $H$. Angiotensin-Converting Enzyme Inhibitory Effects by Ruellia Praetermissa. Pharmaceutical Biology2001; 39: 1619,

5. Wagner H, Bladt S. Plant Drug Analysis, $2^{\text {nd }} E d, 1998$ : Springer Verlag.

6. Salah AM. Chemical and pharmacological investigation of Ruellia praetermissa, Hibiscus Sabdaruiffa and Commelina congesta extracton tracheal, ileal and uterine smoot and papillary mscle of guinea pig: Ph.D. Thesis: 2001.

7. Salah AM. Anti-inflammatory and cardiovascular effects of some chemically active principles from Ruellia praetermissa. Doctorate Thesis; 1999: 75-93.

8. Salah AM, Wagner $H$. Effects of Ruellia praetermissa extract on ovulation, implantation, and the uterine endometrium of female rat. J Med Plants Res 2009; 3(9): 641-645.

9. Ogwumike O. Hemopoietic effect of aqueous extract of the leaf sheath of sorghum bicolor in albino rats African J. of Biomed Res, 2002; 5: 69-71.

10. Sembulingam S, Prem S. Essentials of Medical Physiology. Jaypee brothers Medical Publishers (P) LTD, $5^{\text {th }}$ Ed. 2010: 64-91.

11. Fleur SL. Physiology - A regulatory system approach. MacMillan Publishing Co., INC . $4^{\text {th }}$ Ed. 1998: 268-288.

12. Vander AJ, Sherman JH, Luciano SD. Human Physiology Mechanism of Body Function. McGraw-Hillm INC $6^{\text {th }}$ Ed. 1994: 515-560

13. Duke J. Medicinal Plants of the World. In Computer Index with more than 85,000 entries. 2010: 3 vols.

14. Constanzo LS. Physiology. Sounders - An imprint of Elsevier. $2^{\text {nd }}$ Ed. 2004: 